\title{
Economic Importance of Genetic Improvements in Milk Production, Reproduction, and Productive Life ${ }^{1}$
}

Albert de Vries $^{2}$

\section{Introduction}

Florida dairy producers have access to genetic evaluations for many dairy traits that are economically important. These traits are combined in economic selection indexes to rank bulls and cows for total profitability. The first economic selection index, introduced in 1971 by the USDA-Animal Improvement Programs Laboratory (USDA-AIPL) in Beltsville, MD, included only milk and fat yield. But other traits, such as the ability to get pregnant in time or to avoid culling, determine a cow's profitability as well.

Currently, USDA-AIPL calculates the genetic merit of 11 economically important traits for bulls and cows 4 times per year and combines them into 3 lifetime merit (economic) selection indices. A lifetime merit index is the expected total additional profit, in dollars, during a cow's lifetime (after first calving) as compared to the total profit of a breed average animal. Lifetime is considered to be 3 lactations.

The true economic values of genetic improvement for individual farms depend considerably on the market prices of milk, fat, feed, heifers, cull cows, etc. They vary over time, and from dairy farm to dairy farm. The objective of this paper is to show how USDA-AIPL arrives at its economic values and how the economic values for milk production, reproduction, and productive life on Florida dairies may vary from the USDA-AIPL estimates. Much of the information in this paper is taken from the following documents on the USDA-AIPL website:

http://aipl.arsusda.gov/reference/nmcalc.htm and http://aipl.arsusda.gov/reference/nmcalc-2000.htm.

\section{Genetic Merit Evaluations}

An animal's lifetime merit is a combination of genetic merit and economic value for each trait. Genetic merit of a trait in lactating cows and bulls with daughters is expressed as predicted transmitting ability (PTA). The PTA is half an animal's expected breeding value and is equivalent to the genetic worth that is expected to be transmitted to its offspring. Any offspring's breeding value for a trait will be, on average, the average of its parents' breeding values for that trait. Equivalently, the expected breeding value of a daughter is the sum of the PTAs of her sire

1. This document is AN158, one of a series of the Animal Science Department, Florida Cooperative Extension Service, Institute of Food and Agricultural Sciences, University of Florida. Original publication date November, 2005. Visit the EDIS Web Site at http://edis.ifas.ufl.edu.

2. Albert de Vries, Assistant Professor, Department of Animal Sciences, University of Florida, Institute of Food and Agricultural Sciences, Cooperative Extension Service, Gainesville, 32611.

The Institute of Food and Agricultural Sciences (IFAS) is an Equal Opportunity Institution authorized to provide research, educational information and other services only to individuals and institutions that function with non-discrimination with respect to race, creed, color, religion, age, disability, sex, sexual orientation, marital status, national origin, political opinions or affiliations. U.S. Department of Agriculture, Cooperative Extension Service, University of Florida, IFAS, Florida A. \& M. University Cooperative Extension Program, and Boards of County Commissioners Cooperating. Larry Arrington, Dean 
and dam. The reason that the true breeding value may be different is the result of some "shuffling of the genes" when sperm or eggs are produced. As a result, some offspring are better and some are worse than the average of their parents.

PTAs are expressed as differences from the breed base. The breed base is equivalent to the genetic merit of an average animal in the population and is occasionally recalculated by USDA-AIPL (once every 5 years). Because genetic merit of the population improves over time, a recalculation typically causes all PTAs to be reduced. This recalculation has no affect on the ranking and difference in PTAs between animals, which is what matters.

The PTA for milk production is divided in PTAs for milk yield, fat, and protein. All are measured in total pounds per 305-day lactation in a mature cow. Thus, a PTA milk of 1 implies one pound more milk in 305 days compared to the breed base. The expected lifetime is 3 lactations.

USDA-AIPL provides genetic evaluations for daughter pregnancy rate (DPR) as a measure of reproductive efficiency. DPR is defined as the percentage of nonpregnant cows that become pregnant during each 21-d period. Pregnancy rates on Florida dairy farms range from below $10 \%$ to over $20 \%$. The PTA DPR is expressed as deviations from the breed base. An increase in the PTA DRP of 1 implies a one percentage unit better pregnancy rate, say from $15 \%$ to $16 \%$. Each increase of 1 in PTA DPR equals a decrease of 4 PTA days open per lactation. The PTA DPR is assumed the same for all lactations. More information on DPR can be found at http://aipl.arsusda.gov/reference/fertility/DPR_rpt.htm

Productive life (PL) refers to the time a cow spends in the milking herd since first calving until removal by voluntary or involuntary culling, or death. The PTA PL is expressed in months difference from the herd base. The PTA PL is a measure for total added lifetime (not per lactation). Genetic evaluations for PL are complex and depend on culling data, but also other traits such as type traits and milk yield. More information on the calculation of PL can be found at http://aipl.arsusda.gov/reference/multi-pl.htm.
Table 1 shows the variation in PTAs for milk, fat, protein, DPR and PL in the August 2005 USDA-AIPL Holstein Sire Summaries. The variation between the top and bottom sires is $2825 \mathrm{lbs}$ for $305-\mathrm{d}$ milk, $87 \mathrm{lbs}$ for 305-d fat, $65 \mathrm{lbs}$ for 305-d protein, 4.5 percentage units for DPR, and 7 months for PL.

\section{Genotype by Environment Interactions}

A PTA is the expected genetic improvement of the daughter that is transmitted from the parent compared to the breed base. The PTA is independent of the environment of the farm. This means for example, that the daughters of a sire with PTA milk of $+2000 \mathrm{lbs}$ and a dam with PTA of $+0 \mathrm{lbs}$ are expected to produce $2000 \mathrm{lbs}$ more milk in the first 305 days of a lactation.

Some Florida dairy producers have questioned this theory, arguing that changes in the genetics of their cows cannot easily be observed in the environment of their herds. In reality the amount of genetic progress in the daughter does depend on the environment and management of the farm. Typically, well managed herds will see larger responses than herds where the environment and management is not as favorable for cows. This genotype by environment interaction may cause some reranking of bulls in different geographical areas and management systems. The extent of the reranking depends on the trait and the amount of variation in environment and management. Lowly heritable traits like daughter pregnancy rate $\left(\mathrm{h}^{2} 4 \%\right)$ and productive life $\left(\mathrm{h}^{2}\right.$ $8.5 \%)$ are more susceptible to reranking than higher heritable traits such as milk yield $\left(\mathrm{h}^{2} 25 \%\right)$.

Some studies published in the Journal of Dairy Science (JDS) have recently shed more light on genotype by environment interactions. For example, there is some evidence a bull's daughters may perform differently in large herds versus small herds, or a hot climate versus a cool climate (JDS 86:1009). Genetic progress of production traits may be reduced by as much as half in some grazing herds compared to confined herds (JDS 87:501). On the other hand, one initial study did not find evidence for a genotype by environment interaction for fertility traits (JDS 87:510), despite their low heritability. 
Table 1. Minima and maxima of PTAs for milk, fat, protein, daughter pregnancy rate (DPR), and productive life (PL) in the August 2005 USDA-AIPL Holstein Sire Summaries.

\begin{tabular}{lccccc}
\hline & $\begin{array}{c}\text { PTA Milk } \\
\text { PTA }\end{array}$ & $\begin{array}{c}\text { PTA Fat } \\
(305-d \text { lbs })\end{array}$ & $\begin{array}{c}\text { PTA Protein } \\
(305-d \text { lbs })\end{array}$ & $\begin{array}{c}\text { PTA DPR } \\
(305-d ~ l b s)\end{array}$ & $\begin{array}{c}(\%) \\
\text { Minimum }\end{array}$ \\
\hline Maximum & 285 & 15 & 16 & -2.1 & -2.0 \\
\hline
\end{tabular}

Source: http://aipl.arsusda.gov/.

The genotype by environment interactions are not large enough to justify separate genetic evaluations for each production system (JDS 87:501). In other words, the top bulls remain the top bulls regardless of the type of herd they are in. In well managed herds, the differences between bulls are more pronounced than in herds with poorer environments.

\section{Lifetime Merit Calculations}

Eleven economically important traits are included in the lifetime merit indices. Each trait is assigned an economic value. This value allows dairy producers to compare the value of improvements in, for instance, milk production with the values of improvements in DPR or PL. An economic value is the profit change when a given trait changes by one unit, and all other traits in the index remain the same. For example, an economic value for 1 pound extra fat during a cows lifetime is determined by holding pounds of milk and protein constant and examining the increase in profit when the total lifetime milk yield contains one extra pound of fat.

The economic values used by USDA-AIPL are based on average expected market prices 3 to 5 years in the future, when the daughters of the current animals are in production. Remember too that these are national averages. The lifetime merit indices measure the additional lifetime profit that is expected to be transmitted to an average daughter, but it does not include additional profit that is expected because the daughters of the daughters are also going to be more profitable. Therefore, the value of genetic improvement is probably somewhat underestimated.

Differences in milk pricing throughout the US result in different economic values of genetic improvements in milk and milk components. To account for this, USDA-AIPL calculates 3 lifetime merit indices: net merit (NM\$), fluid merit (FM\$) and cheese merit $(\mathrm{CM} \$)$. Their only difference is the way the milk is valued. The FM\$ index is most appropriate in markets where milk is sold for fluid consumption. Producers who expect future premiums of $<\$ 0.17$ per $0.1 \%$ increase in milk protein should select on FM\$. For Florida dairy producers, the FM\$ index is the best reflection of the way their milk is priced. Producers who expect premiums of $>\$ 0.26$ per $0.1 \%$ increase in milk protein should select on $\mathrm{CM} \$$. Most producers in the US are likely to expect premiums for protein between $\$ 0.17$ and $\$ 0.26$ per $0.1 \%$ increase in milk protein. For them NM $\$$ is most appropriate. The $\mathrm{NM} \$$ index is also the best known lifetime merit index. Table 2 lists the 11 traits, their units, and values that make up the NM\$, FM\$ and $\mathrm{CM} \$$.

The standard deviation (SD) in Table 2 is a measure of the true transmitting ability for that trait in a hypothetical unselected population. It is a measure of how much genetic variation in the trait there is, and thus how much room for improvement.

The economic values in dollars per PTA unit for protein, fat, milk, productive life, and daughter pregnancy rate for the 3 lifetime merit indices will be explained below. The relative value of a trait in the total selection emphasis is calculated as SD $\mathrm{x}$ economic value for that trait, compared to the sum of the SD x economic values for all traits in the lifetime merit index (take the absolute values). For example for $\mathrm{NM} \$$ (using the values in Table 2), $25 \times \$ 4.81+$ $32 \times \$ 2.54++1.4 \times \$ 5.00=\$ 363.25$. Then for example for protein $25 \times \$ 4.81=\$ 120.25$, which is $33 \%$ of $\$ 363.25$. Hence the relative value of protein in the NM\$ is $33 \%$. The economic value of a trait may change when other correlated traits are added to the index. Table 2 shows that only $55 \%$ of the emphasis in the lifetime merit indices is on the milk production traits yield, fat, and protein. 
Table 2. Economic values and relative values of the 11 traits in the net merit (NM\$), fluid merit (FM\$) and cheese merit (CM\$) indices as calculated by USDA-AIPL in 2005.

\begin{tabular}{|c|c|c|c|c|c|c|c|c|}
\hline \multirow[b]{2}{*}{ Trait } & \multirow[b]{2}{*}{ PTA Units } & \multirow{2}{*}{$\begin{array}{c}\text { Standard } \\
\text { Deviation } \\
\text { (SD) }\end{array}$} & \multicolumn{3}{|c|}{$\begin{array}{l}\text { Economic Value } \\
\text { (\$/PTA unit) }\end{array}$} & \multicolumn{3}{|c|}{$\begin{array}{l}\text { Relative Value } \\
(\%)\end{array}$} \\
\hline & & & NM\$ & $\mathrm{CM} \$$ & $\mathrm{FM} \$$ & NM\$ & $\mathrm{CM} \$$ & $\mathrm{FM} \$$ \\
\hline Protein & Pounds & 25 & 4.81 & 6.68 & 1.33 & 33 & 36 & 9 \\
\hline Fat & Pounds & 32 & 2.54 & 2.54 & 2.54 & 22 & 18 & 22 \\
\hline Milk yield & Pounds & 832 & 0 & -0.056 & 0.104 & 0 & -10 & 24 \\
\hline Productive life & Months & 1.5 & 26 & 26 & 26 & 11 & 9 & 11 \\
\hline Somatic cell score & Log & 0.2 & -166 & -166 & -166 & -9 & -7 & -9 \\
\hline Udder & Composite & 0.78 & 33 & 33 & 33 & 7 & 6 & 7 \\
\hline Feet/legs & Composite & 0.88 & 15 & 15 & 15 & 4 & 3 & 4 \\
\hline Body size & Composite & 0.94 & -12 & -12 & -12 & -3 & -2 & -3 \\
\hline Daughter pregnancy rate & Percent & 1.4 & 17 & 17 & 17 & 7 & 5 & 7 \\
\hline Service sire calving difficulty & Percent & 1.7 & -5 & -5 & -5 & -2 & -2 & -2 \\
\hline Daughter calving difficulty & Percent & 1.4 & -5 & -5 & -5 & -2 & -2 & -2 \\
\hline
\end{tabular}

As an example, the calculation of the FM\$ and its reliability is demonstrated for a particular Holstein in Table 3. For Holsteins, a value of $8 \%$ must be subtracted from the PTAs for service sire calving difficulty and daughter calving difficulty and the value 3.1 must be subtracted from the PTA for somatic cell score. The lifetime economic value of this animal above the breed base is estimated to be $\$ 675$. The reliability of her FM\$ index can be approximated as the reliability of milk yield $\mathrm{x} 0.85$ plus the reliability of productive life $\mathrm{x} 0.15$. In this example, $90 \times 0.85+60 \times 0.15=86 \%$. The reliability of a trait is a measure of the strength of the relationship between its true genetic merit and its predictions. It depends heavily on the amount of data that is available to calculate an animal's PTA for a trait.

The PTAs that are calculated for an animal are adjusted for genetic improvements in the other traits. However, sometimes strong genetic correlations exist between traits. For example, if a dairy producer only selected for milk yield, that producer would also see genetic increases in fat, protein, PL, somatic cell score, and size. The genetic merit of other traits would decrease. Publication http://aipl.arsusda.gov/reference/nmcalc.htm lists these genetic correlations.

\section{Economic Value of Milk Production}

The differences between the $\mathrm{NM} \$$, FM $\$$, and $\mathrm{CM} \$$ indices lie in the way milk components are priced. Table 4 lists the USDA-AIPL prices for protein, fat, and milk yield and the resulting economic values. The economic values are calculated as (component price - feed cost) x $0.89 \times 3$ lactations. The constant 0.89 is used to convert mature equivalent yield to actual yield. For example, $1 \mathrm{lb}$ of fat per lactation is worth $\$ 1.30$ but the feed cost to produce it is $\$ 0.35$. Therefore, profit per lactation is on average $(\$ 1.30-\$ 0.35) \times 0.89=$ $\$ 0.85$ and for all 3 lactations (lifetime) it is $\$ 0.85 \times 3$ $=\$ 2.54$. For FM $\$$, most of the value comes from increasing fat yield and some from increasing protein yield. Milk yield by itself has little value. It is clear that none of the merit indices are exactly correct for Florida producers who currently don't get paid for protein.

One pound of mature equivalent milk with $3.5 \%$ fat and $3.0 \%$ protein is worth $1 \times \$ 0.051+0.035 \mathrm{x}$ $\$ 1.30+0.03 \times \$ 1.00=\$ 0.1265$. The feed costs to produce this pound of mature equivalent milk are $1 \mathrm{x}$ $\$ 0.012+0.035 \times \$ 0.35+0.03 \times \$ 0.50=\$ 0.039$. The economic value of a pound of actual milk with $3.5 \%$ fat and $3.0 \%$ protein in one lactation (305-days) in the FM\$ index is therefore $(\$ 0.1265-\$ 0.039)$ x 0.89 $=\$ 0.078$ or $\$ 0.233$ lifetime (3 lactations). The economic value happens to be the same for the NM\$ index. In other words, USDA-AIPL assumes that the 
Table 3. Example calculation of the fluid merit (FM\$) of a Holstein animal.

\begin{tabular}{|c|c|c|c|c|}
\hline Trait & PTA & Reliability (\%) & $\begin{array}{l}\text { Economic Value } \\
\text { (FM, \$/PTA unit) }\end{array}$ & $\begin{array}{c}\text { Lifetime Economic } \\
\text { Value (\$) }\end{array}$ \\
\hline Protein & +70 & 90 & 1.33 & 93.10 \\
\hline Fat & +80 & 90 & 2.54 & 203.20 \\
\hline Milk yield & $+2,000$ & 90 & 0.104 & 208.00 \\
\hline Productive life & +2.5 & 60 & 26 & 65.00 \\
\hline Somatic cell score & $+3(-3.1)$ & 75 & -166 & 16.60 \\
\hline Udder & +1.5 & 80 & 33 & 49.50 \\
\hline Feet/legs & +0.5 & 75 & 15 & 7.50 \\
\hline Size & -1 & 85 & -12 & 12.00 \\
\hline Daughter pregnancy rate & +0.3 & 55 & 17 & 5.10 \\
\hline Service sire calving difficulty & $+6(-8)$ & 90 & -5 & 10.00 \\
\hline \multirow[t]{3}{*}{ Daughter calving difficulty } & $+7(-8)$ & 60 & -5 & 5.00 \\
\hline & & & $\mathrm{FM} \$$ & 675.00 \\
\hline & & & Reliability( estimated) & $86 \%$ \\
\hline
\end{tabular}

Table 4. Milk component prices and economic values used by USDA-AIPL.

\begin{tabular}{lccc}
\hline Index & Milk yield $(\$ / \mathrm{lbs})$ & Fat $(\$ / \mathrm{lbs})$ & Protein $(\$ / \mathrm{lbs})$ \\
\hline NM\$ price & 0.012 & 1.30 & 2.30 \\
CM\$ price & -0.009 & 1.30 & 3.00 \\
FM\$ price & 0.051 & 1.30 & 1.00 \\
Feed cost & -0.012 & -0.35 & -0.50 \\
Lifetime (\# lactations) & 3 & 3 & 3 \\
& & & \\
Economic Values & & & 4.81 \\
NM\$ (lifetime) & 0.000 & 2.54 & 6.68 \\
CM\$ (lifetime) & -0.056 & 2.54 & 1.34 \\
FM\$ (lifetime) & 0.104 & 2.54 & \\
\hline
\end{tabular}

economic value of marginal milk income over marginal feed cost is $\$ 0.078$ per pound. Remember that these assumptions apply to 3 to 5 years into the future when actual production of the offspring takes place.

The average feed cost on dairies in Florida ranges from $\$ 0.06$ to $\$ 0.08$ per pound of milk. At a $\$ 0.17$ milk price, this means an income over feed cost in the range of $\$ 0.09$ to $\$ 0.11$. However, some of the feed takes care of body maintenance. The marginal value of an extra pound of milk in Florida is therefore probably significantly higher than $\$ 0.078$. How this impacts the economic values in the lifetime merit indices depends on the pricing of the components. If, for example, the milk component prices are simply multiplied by the ratio of the marginal value per extra pound of milk and 0.078 (for example $\$ 0.100$ /
$\$ 0.078=1.288)$ then the economic values in Table 5 appear. It is evident that the economic value of genetic increases in milk production could be significantly greater in Florida than is currently assumed by USDA-AIPL. These estimates assume that increases in milk production are not associated with any other cost.

\section{Economic Value of Reproduction}

The PTA DPR is calculated from information on days open (days that the cow is nonpregnant and eligible for breeding). USDA-AIPL uses the following assumptions to estimate the cost of an extra day open. Semen cost (\$15/unit) and breeding labor cost (\$5/unit) are counted once per 40 days open. This is $(\$ 15+\$ 5) \times 0.025=\$ 0.50$ per day open. Cost for heat detection and labor, $\$ 20$ per lactation, are 
Table 5. Possible economic values of milk yield, fat and protein per PTA unit and lifetime value of 1 pound extra milk with $3.5 \%$ fat and $3.0 \%$ protein per lactation. The components of the FM\$ index are multiplied by marginal income over feed cost divided by 0.078 (factor).

\begin{tabular}{cccccc}
\hline $\begin{array}{c}\text { Marginal income over } \\
\text { feed cost }(\$ / \mathrm{lbs})\end{array}$ & Factor & $\begin{array}{c}\text { Milk yield } \\
\text { (\$/PTA unit) }\end{array}$ & $\begin{array}{c}\text { Fat } \\
\text { (\$/PTA } \\
\text { unit) }\end{array}$ & $\begin{array}{c}\text { Protein } \\
\text { (\$/PTA unit) }\end{array}$ & $\begin{array}{c}1 \text { lbs milk with } 3.5 \% \text { fat } \\
\text { and 3.0\% protein }(\$ \\
\text { lifetime) }\end{array}$ \\
\hline 0.070 & 0.901 & 0.091 & 2.194 & 1.072 & 0.200 \\
$0.078^{*}$ & 1.000 & 0.104 & 2.537 & 1.335 & 0.233 \\
0.080 & 1.030 & 0.108 & 2.641 & 1.416 & 0.243 \\
0.100 & 1.288 & 0.143 & 3.535 & 2.103 & 0.330 \\
0.120 & 1.545 & 0.178 & 4.429 & 2.791 & 0.417 \\
\hline
\end{tabular}

${ }^{*}$ Current USDA-AIPL assumption.

multiplied by 0.005 to result in $\$ 0.10$ per day open. Labor cost for pregnancy diagnosis is $\$ 10 /$ exam. This multiplied by 0.012 exams per day open results in a cost of $\$ 0.12 /$ day open. Because extra days open cause more cows to be later in lactation, the reduction in milk sales is estimated at $\$ 0.75$ per day open. This does not include the increased cost for cow replacement due to reproductive failure because that is included in the cost of productive life. Together, the cost per day open in each lactation is estimated at $\$ 0.50+\$ 0.10+\$ 0.12+\$ 0.75=\$ 1.47$, or rounded $\$ 1.50$.

The lifetime value of 1 day open per lactation is $2.8 \times \$ 1.50=\$ 4.20$. The factor 2.8 is based on the assumption that fewer breedings are attempted in the third lactation and includes an adjustment for heifer fertility. Because 4 days open is equal to $1 \%$ DPR, the economic value of 1 unit PTA DPR is $4 \times \$ 4.20=$ $\$ 16.80$, or rounded $\$ 17$. This is the DPR value in Table 2.

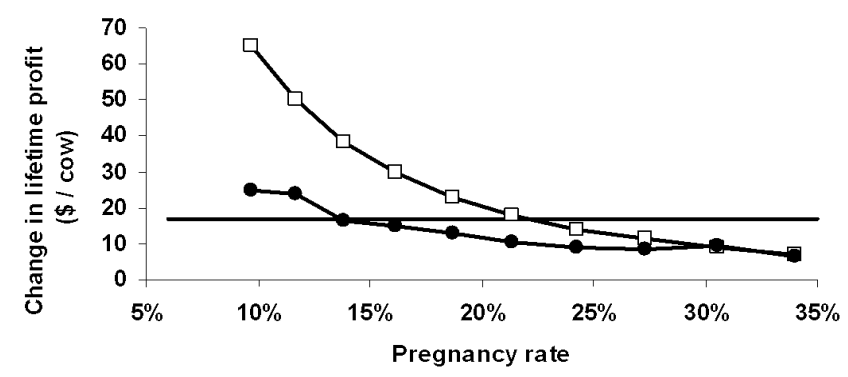

Figure 1. Change in lifetime profit per cow for a change of one percentage unit in pregnancy rate. The top curve ( $\square$ ) is change in lifetime profit including the cost of cow replacement. The bottom curve $(\bullet)$ is the change in lifetime profit per cow excluding cow replacement cost. The USDAAIPL estimate $(-)$ of $\$ 17$ also excludes cow replacement cost. Lifetime is 3 lactations.

Many studies have shown that the value of a 1 percentage-unit increase in pregnancy rate increases when the average pregnancy rate in the herd is lower. Often these estimates include the cost of cow replacement. Figure 1 shows some estimates of the change in lifetime profit per cow per percentage unit change in pregnancy rate for a simulated typical Florida herd. Pregnancy rate was varied from $10 \%$ to $34 \%$. The annual cull rate decreased from $38 \%$ when pregnancy rate was $10 \%$, to $30 \%$ when pregnancy rate was $34 \%$. The economic value of a one-percentage-unit change in pregnancy rate ranged from $\$ 7$ to $\$ 65$ when the cost of increased cow replacement was included. However, if the cost of increased cow replacement was excluded, then the change in lifetime profit ranged from only $\$ 6$ to $\$ 25$. These latter values can be compared to the USDA-AIPL estimate of $\$ 17$. A major component of the economic value of a change in pregnancy rate results from cow replacement costs. Other values could be obtained under different assumptions such as the amount of involuntary culling and milk production. However, the economic value of genetic improvement in DPR clearly depends on the average pregnancy rate in the herd and can be significantly higher or lower than $\$ 17$.

\section{Economic Value of Productive Life}

The USDA-AIPL estimate of the value of PL assumes that a culled cow is going to be replaced with a heifer. That is, it accounts for the opportunity cost of delayed replacement because extending the productive life of one cow denies the opportunity to make a profit with a replacement animal in the same slot.

The basic calculation of the economic value of productive life is (heifer price - beef price) / lifetime. In 2000, USDA-AIPL assumed a heifer 
Table 6. Estimates of the economic value of productive life for various heifer prices and herd lifetimes.

\begin{tabular}{cccccc}
\hline & & $25 \%$ & $35 \%$ & $45 \%$ & $\begin{array}{c}\text { Annual cull rate } \\
\text { Beef price }\end{array}$ \\
\cline { 3 - 6 } & Heifer price & 48.1 & 34.3 & 26.7 & $\$ 29$ \\
525 & 1300 & $\$ 16$ & $\$ 23$ & $\$ 44$ \\
525 & 1700 & $\$ 24$ & $\$ 34$ & $\$ 59$ & \\
\hline
\end{tabular}

price of $\$ 1240$ and a beef price of $\$ 525$. The economic value of 1 month PTA PL could therefore simply be estimated as $(\$ 1240-\$ 525) / 30=\$ 24$, but USDA-AIPL used $\$ 28$ per month. Currently, the economic value of 1 month PTA PL is set at \$26 per month. This value can be considered the straight-line monthly depreciation of a dairy cow.

Heifer prices and average lifetime vary significantly on Florida dairies, for example because producers raise or purchase their heifers and because cull rates vary. Table 6 shows how the economic value of 1 month PTA PL varies from $\$ 16$ to $\$ 59$ for different heifer prices and annual cull rates. Lifetime (in months) is calculated as $1 /$ annual cull rate $\mathrm{x} 12$. The economic value of PL on Florida dairies can be significantly different from the $\$ 26$ that is currently used in the lifetime merit indices.

\section{Economic Value of Other Traits}

The economic values of the other traits in the lifetime merit indices on Florida dairy farms are likely to differ from the USDA-AIPL assumptions as well. For example, the economic value of 1 unit PTA somatic cell score is $\$ 166$, but this includes a large premium for reductions in somatic cell count. Currently no such premiums exist in Florida.

Instead of using the linear type traits directly in the lifetime merit indices, USDA-AIPL uses composite scores for udder, feet/legs, and size calculated as functions from the linear type traits. The economic values of the type traits vary as well from farm to farm. For example, when parlor capacity is a constraint, it is important to maximize parlor throughput. This means that cows need to enter and exit the parlor quickly. They can only do so if their feet and legs allow them to move quickly and if they can be easily and quickly milked. This will increase the economic value of 1 unit PTA for foot or leg and udder traits on such farms.

\section{Relative Value of Improvements in Milk Production, Daughter Pregnancy Rate, and Productive Life}

Because the economic values in the lifetime merit indices in Table 2 are all expressed as lifetime benefits, we can easily compare the relative value of 1 unit change in milk production, DPR, and PL. Table 7A lists the economic values for these traits for USDA-AIPL and two hypothetical farms A and B. Farm A has a low cull rate and raises its own heifers and its pregnancy rate is high. Farm B has a higher cull rate and a lower pregnancy rate. The lifetime marginal value of $1 \mathrm{lb}$ milk in 305 days is assumed to be $\$ 0.33$. Table $7 \mathrm{~B}$ is a comparison of the relative values of a 1 unit increase in one trait compared to increases in other traits. For example, using the USDA-AIPL economic values, the value of 1 month extra PL is equivalent to $111.59 \mathrm{lbs}$ more milk $(3.5 \%$ fat, $3.0 \%$ protein) per 305 days in each lactation.

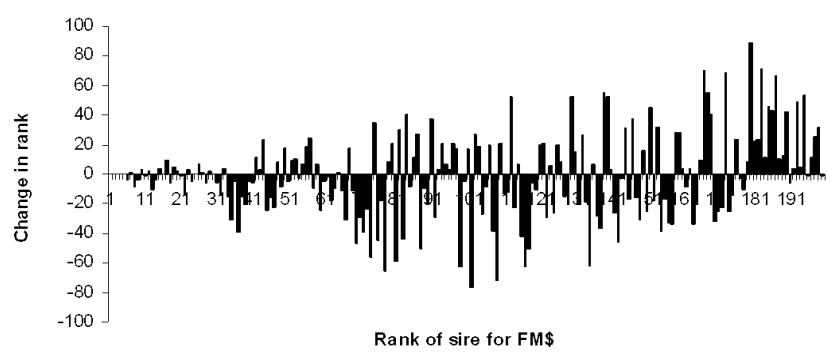

Figure 2. Effect of using economic values of $\$ 36$ for productive life and $\$ 24$ for daughter pregnancy rate on the ranking of the top 200 all Holstein sires evaluated by USDA-AIPL for FM\$ in August 2005. The $y$-axis is the change in ranking compared to the USDA-AIPL ranking. The top 5 sires don't change their ranking. The $6^{\text {th }}$ ranked sire by USDA-AIPL would rank $10^{\text {th }}$ with the new economic values, a change of -4 .

Ideally, every dairy should use its own expected economic values to rank bulls and cows for lifetime merit. But the effect of using different economic values for PL and DPR on the ranking and merit of the top 200 all Holstein sires evaluated by USDA-AIPL for FM\$ in August 2005 is minor. The maximum FM\$ is \$707 and the minimum \$419 using the USDA-AIPL estimates. Using the new economic values of \$36 for PL and \$24 for DPR (high cull rate and low pregnancy rate), Figure 2 shows the effect on 
the ranking of the 200 sires. The y-axis is the change

in the ranking compared to the USDA-AIPL

calculated ranking (x-axis). The top 5 sires don't

change their ranking. The sire ranked $6^{\text {th }}$ by

USDA-AIPL would rank $10^{\text {th }}$ with the new economic values, a change of -4 . The maximum shifts in ranking are +89 places and -77 places. Figure 1 shows that the effect on the ranking of the top 40 sires is minimal. The genetic merit improves at most $\$ 65$ or decreases at most $\$ 25$. The results are similar for a farm with a low cull rate and a high pregnancy rate, assuming low economic values for PL and DPR. It appears that the ranking of sires by $\mathrm{FM} \$$ is quite robust against reasonable variations in economic values from farm to farm. For practical purposes, the USDA-AIPL ranking of sires seems adequate under conditions in Florida.

\section{Conclusions and Implications}

The lifetime merit indices $\mathrm{NM} \$$ and $\mathrm{FM} \$$ provide Florida dairy breeders valuable tools to select the most profitable bulls. Using the USDA-AIPL economic estimates, 1 month productive life is worth $112 \mathrm{lbs}$ milk in a lactation of 305 days (3.5\% fat and $3.0 \%$ protein) or $1.5 \%$ daughter pregnancy rate. One percent daughter pregnancy rate is worth $73 \mathrm{lbs}$ milk in a 305-day lactation. The genetic progress and economic values for the 11 traits that make up these merit indices depend on the environment and management of the farm. Less genetic progress may be observed on farms where the environment is not as favorable for cows. The economic value of improvements in genetic merit for daughter pregnancy rate and productive life are significantly greater on farms that do not do as well in these areas. The economic value of genetic merit of milk production depends on marginal income over feed cost. Collectively, both factors have some effect on the ranking of bulls by the lifetime merit indices, but the USDA-AIPL ranking of sires seems adequate under conditions in Florida. 
Economic Importance of Genetic Improvements in Milk Production, Reproduction, and....

Table 7a. Economic values for productive life (PL), daughter pregnancy rate (DPR), and milk according to USDA-AIPL and for 2 hypothetical farms A and B.

\begin{tabular}{lccc}
\hline & USDA-AIPL & Farm A & Farm B \\
\hline 1 month PL & $\$ 26$ & $\$ 16$ & $\$ 36$ \\
$1 \%$ DPR & $\$ 17$ & $\$ 10$ & $\$ 24$ \\
1 lbs milk in 305-days & $\$ 0.233$ & $\$ 0.33$ & $\$ 0.33$ \\
\hline
\end{tabular}

${ }^{*}$ Milk with $3.5 \%$ fat and $3.0 \%$ protein.

Table $7 \mathrm{~b}$. value of improvements in 1 unit PTA productive life (PL), daughter pregnancy rate (DPR), and milk according to USDA-AIPL and for 2 hypothetical farms A and B.

\begin{tabular}{lccccll}
\hline & USDA-AIPL & Farm A & & Farm B & & \\
\cline { 2 - 3 } \cline { 5 - 6 } 1 month PL is worth: & 111.59 & 48.48 & & 109.09 & & Lbs 305-day milk* \\
1 month PL is worth: & 1.53 & 1.60 & 1.50 & & $\%$ DPR \\
$1 \%$ DPR is worth: & 72.96 & 30.30 & 72.73 & & Lbs 305-day milk* \\
\hline
\end{tabular}

*Milk with $3.5 \%$ fat and $3.0 \%$ protein. 